\title{
Antimicrobial Activity of Syagrus coronata (Martius) Beccari
}

\author{
Alice Ferreira da Silva Hughes ${ }^{1,4}$, Fabíola Guedes de Lima ${ }^{1}$, Angélica Maria Lucchese ${ }^{2,4}$, \\ Aristóteles Góes Neto ${ }^{1,4}$ and Ana Paula Trovatti Uetanabaro ${ }^{3,4^{*}}$ \\ ${ }^{1}$ Laboratório de Pesquisa em Microbiologia; Departamento de Ciências Biológicas; Universidade Estadual de \\ Feira de Santana; 44036-900; Feira de Santana - BA - Brasil. ${ }^{2}$ Laboratório de Química de Produtos Naturais e \\ Bioativos; Departamento de Ciências Exatas; Universidade Estadual de Feira de Santana; 44036-900; Feira de \\ Santana - BA - Brasil. ${ }^{3}$ Laboratório de Microbiologia da Agroindústria e Departamento de Ciências Biológicas; \\ Universidade Estadual de Santa Cruz; 45662-900, Ilhéus - BA - Brasil. Programa de Pós-graduação em \\ Biotecnologia; Universidade Estadual de Feira de Santana; 44036-900; Feira de Santana - BA - Brasil
}

\begin{abstract}
This work aimed to evaluate the antimicrobial activity of aqueous and methanol extracts of leaves, inflorescences, nut-shell, liquid and solid endosperm nuts of Syagrus coronata against pathogenic bacteria and yeast. Screening was initially performed using the agar dilution method. The extracts regarded as bioactive underwent liquid-liquid partition for determination of their minimum inhibitory concentration and minimum bactericide concentration (MIC and $M B C$ ) and those of their respective fractions against the microorganisms inhibited in preliminary tests. Antimicrobial activity was observed only in inflorescences. The corresponding aqueous extract was effective against B. cereus and the three strains of S. aureus, and the corresponding MIC and MCB values were lower than those of dichloromethane, ethyl acetate and butanol fractions of the same extract. The methanol extract was effective against $\mathrm{B}$. cereus, and the corresponding MIC and MBC values were higher than those of ethyl acetate and butanol fractions of the same extract.
\end{abstract}

Key words: Syagrus coronata, Arecaceae, antimicrobial activity

\section{INTRODUCTION}

The biological activity of medicinal plants has been the subject of intense scientific investigation. Higher aromatic plants are widely used in folk medicine for their broad spectrum of activities and their known inhibitory properties against the pathogenic bacteria and fungi (Hulin et al. 1998). There are many antimicrobial activity studies with the members of the Arecaceae family (Venkataraman et al. 1980, Esquenazi et al. 2002) and the Syagrus genus (Silveira et al. 2005), which are popularly used for the treatment of several diseases due to their tonic, carminative, stomachic, vermifuge, antithermic and cicatrizant properties (Hadi and Bremner 2001, Silveira et al. 2005). The Arecaceae family has been investigated for its antimicrobial activity based on the following criteria: (i) medicinal use of the plants and their possible content of antimicrobial compounds (Esquenazi et al. 2002, Silveira et al. 2005, Agra et al. 2008, Rufino et al. 2008); (ii) chemical composition, since alkaloids (sometimes pyrimidine), proanthocyanidines, flavonoids, saponines and triterpene methyl esters may be present (reviewed in Silveira et al. 2005); (iii)

*Author for correspondence: anapaula.uetanabaro@pq.cnpq.br 
large geographic distribution area, with species found in many parts of Brazil, especially in the Northeast and Southeast (Lorenzi 2000).

Syagrus coronata (Martius) Beccari belongs to the Arecoideae subfamily (Noblick 1991). This is the largest subfamily of Arecaceae, with 115 genera and 1500 species to-date (Uhl et al. 1995). Among several names by which the species is popularly known in Brazil, licuri is mostly used in the outskirts of the state of Bahia; other names such as ouricuri, aricuri, nicuri, coqueiro dicori, coqueirocabeçudo-alicuri, and baba-de-boi are occasionally used (Bondar 1938, Crepaldi et al. 2004).

$S$. coronata has also been used in folk medicine from some regions in Northeastern Brazil. Some of the parts of the plant used in medicinal applications include the nut-shell for snake bites (Agra et al. 2008), coconut water (liquid endosperm) as drops for eye inflammation, mycoses (Tinea negra and Tinea versicolor) and wound healing; and licuri root tea, indicated for the treatment of spinal pain (Rufino et al. 2008). Furthermore, $S$. coronata is a source for candle and soap making products and plays an important role in the subsistence economy of the semi-arid parts of the state of Bahia, through the trade of manufactured products made from different parts of the plant (Crepaldi et al. 2004) and artisanal production of feed (Gonçalves et al. 2005).

The purpose of this study was to evaluate the antimicrobial activity of the extract and fractions of Syagrus coronata (licuri), for potentially using these products as phytotherapeutic agents in the medicinal and/or cosmetic formulations for human use, as well as provide scientifically-grounded primary data about the potential use of species from semi-arid regions.

\section{MATERIALS AND METHODS}

\section{Collection of Materials}

S. coronata (Mart.) Becc. was collected from five specimens in the city of Feira de Santana in the state of Bahia, Brazil. In November 2005, inflorescences and leaves were collected, and in February and April 2006, unripe and ripe nuts, respectively, were collected from the same previously marked specimens. The samples were deposited in the Herbarium of Universidade Estadual de Feira de Santana (HUEFS) and registered under the numbers 114796, 114797, 114798,114799 and 1147800 . The materials were identified by comparison with exsiccates identified by the experts and also based on specialized literature (Noblick 1991).

\section{Obtainment of the Crude Extract Crude Aqueous Extract}

Sixty grams of fresh material (leaves, inflorescences, nut-shell and solid endosperm) was macerated with $600 \mathrm{~mL}$ of distilled water. The extracts were filtered using filter paper and submitted to shaking at $200 \mathrm{rpm}$ at room temperature for $3 \mathrm{~h}$. Subsequently, the extracts were filtered and the plant residues were reextracted with $600 \mathrm{~mL}$ of distilled water. The liquid endosperm of unripe nuts was collected using a $3.0 \mathrm{ml}$ syringe and then filtered to complete the final volume of $300 \mathrm{~mL}$. All the filtrates were lyophilized and stored at $-80{ }^{\circ} \mathrm{C}$ until the trials.

\section{Crude Methanol Extract}

The dried leaf, inflorescence, nut-shell and solid endosperm materials $(60 \mathrm{~g})$ were crushed in absolute methanol $(500 \mathrm{~mL})$ and left for 7 days at room temperature. Subsequently, the extracts were filtered and the plant residues were re-extracted with $500 \mathrm{~mL}$ of methanol. The filtrates were concentrated by rotary evaporation under reduced pressure until completely dried (Chechinel Filho and Yunes 1998). Concentrated materials were stored at $-80{ }^{\circ} \mathrm{C}$ until the trials.

\section{Obtainment of crude extract fractions}

The extracts showing bioactivity on the agar diffusion test were subjected to fractioning. The methanol extract $(10 \mathrm{~g})$ was dissolved in $200 \mathrm{~mL}$ of absolute methanol and $60 \mathrm{~mL}$ of distilled water, while the aqueous extract $(10 \mathrm{~g})$ was dissolved in $260 \mathrm{~mL}$ of distilled water. The extracts were then subjected to liquid-liquid partition with solvents of increasing polarity, namely hexane, dichloromethane, ethyl acetate and butanol. The concentration and storage of the fractions were performed as described above for methanol extracts.

\section{Antimicrobial Activity}

Test Microorganisms

The antimicrobial activity of the extracts was tested against the Bacillus cereus CCMB 282, Escherichia coli CCMB 284, E. coli CCMB 261, sensitive to trimetoprim and resistant to sulphonamide, Pseudomonas aeruginosa CCMB 
264, Salmonella choleraesuis CCMB 281, Staphylococcus aureus CCMB 285, S. aureus CCMB 262, resistant to streptomycin and dihydrostreptomycin, S. aureus CCMB 263, resistant to novobiocin, and against Candida albicans CCMB 266, C. albicans CCMB 286, resistant to amphotericin-B and fluconazole, and Malassezia furfur CCMB 293. These microorganisms were cultured in Müeller-Hinton Agar (MHA) medium, except for M. furfur which was cultured in Sabouraud agar added with longchain fatty acids ( $2 \%$ glucose, $1 \%$ peptone, $0.5 \%$ yeast extract, $1 \%$ olive oil, $3 \%$ bovine bile, $5 \%$ Tween $80,2 \%$ agar, $0.1 \%$ chloramphenicol), modified Sadrim and Rocha (2004) medium, and incubated at $37^{\circ} \mathrm{C}$ (bacteria) and $28^{\circ} \mathrm{C}$ (yeasts) for 24 and $48 \mathrm{~h}$, respectively. The test strains were provided by the Microorganism Cultures Collection of the state of Bahia (CCMB/UEFS).

\section{Agar Diffusion Test}

Initial screening for antimicrobial activity was performed using the agar diffusion method with slightly modified filter paper disks (Bauer et al. 1966). A suspension of the test organism $(0.1 \mathrm{~mL}$ of the MacFarland 0.5 scale for bacteria and 0.1 $\mathrm{mL}$ of the MacFarland 3 scale for yeasts) was spread onto a Sabouraud agar-covered surface added with long-chain fatty acids as previously mentioned for M. furfur, and MHA (approximately $25 \mathrm{~mL}$ ) for other test microorganisms on a Petri dish (100 mm diameter x $15 \mathrm{~mm}$ height). The filter paper disks (6 $\mathrm{mm}$ diameter) were impregnated with $5.0 \mu \mathrm{L}$ of the crude extract samples at initial concentrations of 200, 100 and $50 \mathrm{mg} / \mathrm{mL}$ and placed on the plates inoculated with the test microorganisms. Extract-containing disks were air dried at room temperature for solvent evaporation. Nystatin (10 $\mu \mathrm{g} / \mathrm{disk})$ and chloramphenicol (30 $\mu \mathrm{g} / \mathrm{disk}$ ) samples were selected as standards for the comparison of results. Inoculated plates containing the extract-impregnated disks and controls were incubated as previously described. The diameters of inhibition zones, including the disk diameter, were measured using a millimeter ruler. Tests were performed in triplicate and the average diameter was calculated for each test.

\section{Determination of the Minimum Inhibitory Concentration (MIC)}

Extracts showing antimicrobial activity on the agar diffusion test and their respective fractions underwent broth microdilution tests for the determination of the minimum inhibitory concentration (MIC) against the bacteria inhibited (CLSI 2003) in the aforementioned preliminary trial. Tests were performed in Müeller-Hinton broth. The aqueous extract was re-suspended in the water, while the methanol extract and other fractions were re-suspended in $25 \%$ of dimethylsulfoxide (DMSO) and then sterilized by filtration through an acetate cellulose membrane $(0.22 \mu \mathrm{m})$. Serial dilutions of $100 \mathrm{mg} / \mathrm{mL}$ at $0.0488 \mathrm{mg} / \mathrm{mL}$ were prepared from the extracts and fractions on sterile 96-well microtitration plates. Each well then received $10 \mu \mathrm{L}$ of the test microorganism suspension $\left(1.5 \times 10^{5} \mathrm{UFC} / \mathrm{mL}\right.$ per well $)$. The plates were incubated at $37{ }^{\circ} \mathrm{C}$ for $24 \mathrm{~h}$. A purity verification of the suspension was performed by subculture of a corresponding aliquot on MHA plate for simultaneous incubation. After incubation, $50 \mu \mathrm{L}$ of aqueous TTC (triphenyl tetrazole chloride) solution at $0.5 \%$ were added to each of the wells and the microplates were reincubated for three more hours, as reported by Custódio et al. (2010), at $37^{\circ} \mathrm{C}$ for qualitative assessment of microbial growth. Chloramphenicol dilutions ( 6 at $0.0488 \mathrm{mg} / \mathrm{mL}$ ) were used as the controls for data comparison between the independent experiments and as indicators for relative evaluation of the inhibition level of the samples tested. Controls were also prepared for viability assessment of the test microorganisms and sterility assessment of the culture medium and the solvent used for dissolution of extracts and fractions, for verification of any possible effects on microorganisms. All the tests were performed in triplicate.

The activity pattern used for interpretation of minimum inhibitory concentrations was based on the values established by Aligiannis et al. (2001): strong inhibition, MIC lower than $0.5 \mathrm{mg} / \mathrm{mL}$; moderate inhibition, MIC between 0.6 and 1.5 $\mathrm{mg} / \mathrm{mL}$; and poor inhibition, MIC higher than 1.5 $\mathrm{mg} / \mathrm{mL}$.

\section{Determination of the Minimum Bactericide Concentration $(M B C)$}

For the determination of the minimum bactericide concentration (MBC), the wells showing bacterial development inhibition in the MIC trial were selected. A sample of $20 \mu \mathrm{L}$ was removed from each of these wells and inoculated onto MHA plates at $37{ }^{\circ} \mathrm{C}$ for $24 \mathrm{~h}$. After incubation, the cultures were inspected for visual verification of microbial growth. All the tests were performed in 
triplicate. The MBC was defined as the lowest concentration yielding negative subcultures or only one colony (Sanches et al. 2005).

\section{RESULTS}

The aqueous inflorescence extract was the only among all the aqueous extracts tested by agar diffusion to show antimicrobial activity, particularly against $B$. cereus and the three strains of $S$. aureus (Table 1). The methanol inflorescence extract was the only to show antibacterial activity against $B$. cereus with halos of 10 and $8 \mathrm{~mm}$ for the concentrations of 1000 and $500 \mu \mathrm{g} / \mathrm{disk}$, respectively. The minimum inhibitory concentration (MIC) and the minimum bactericide concentration (MBC) of the aqueous and methanol licuri inflorescence extracts and fractions against B. cereus CCMB 282, S. aureus CCMB 262, 263 and 285 were quantitatively analyzed based on the values in Table 2. The yield for the hexane fraction of the aqueous inflorescence extract was null and thus MIC and MBC could not be calculated.

Table 1 - Average diameters $(\mathrm{mm})$ of inhibition zones of aqueous $S$. coronata extracts and controls against test microorganisms as determined by agar diffusion tests.

\begin{tabular}{|c|c|c|c|c|c|c|c|c|c|c|c|c|c|c|c|c|}
\hline \multicolumn{17}{|c|}{ Inhibition zones (mm) } \\
\hline \multirow[t]{2}{*}{ Microorganisms } & \multicolumn{3}{|c|}{ Leaves } & \multicolumn{3}{|c|}{ Inflorescences } & \multicolumn{3}{|c|}{$\begin{array}{c}\text { Liquid } \\
\text { endosperm }\end{array}$} & \multicolumn{3}{|c|}{$\begin{array}{c}\text { Solid } \\
\text { endosperm }\end{array}$} & \multicolumn{3}{|c|}{ Nut Shell } & \multirow[t]{2}{*}{ Controls } \\
\hline & C1 & $\mathrm{C2}$ & $\mathrm{C3}$ & C1 & $\mathrm{C2}$ & $\mathrm{C3}$ & $\mathrm{C1}$ & $\mathrm{C2}$ & $\mathrm{C3}$ & C1 & $\mathrm{C2}$ & C3 & C1 & $\mathrm{C2}$ & $\mathrm{C3}$ & \\
\hline B.c CCMB 282 & 0 & 0 & 0 & 14 & 12 & 10 & 0 & 0 & 0 & 0 & 0 & 0 & 0 & 0 & 0 & $32 *$ \\
\hline E.c CCMB 284 & 0 & 0 & 0 & 0 & 0 & 0 & 0 & 0 & 0 & 0 & 0 & 0 & 0 & 0 & 0 & $9^{*}$ \\
\hline E.c CCMB 261 & 0 & 0 & 0 & 0 & 0 & 0 & 0 & 0 & 0 & 0 & 0 & 0 & 0 & 0 & 0 & $0 *$ \\
\hline P.a CCMB 264 & 0 & 0 & 0 & 0 & 0 & 0 & 0 & 0 & 0 & 0 & 0 & 0 & 0 & 0 & 0 & $0 *$ \\
\hline S.a CCMB 262 & 0 & 0 & 0 & 12 & 10 & 8 & 0 & 0 & 0 & 0 & 0 & 0 & 0 & 0 & 0 & $12 *$ \\
\hline S.a CCMB 263 & 0 & 0 & 0 & 12 & 10 & 8 & 0 & 0 & 0 & 0 & 0 & 0 & 0 & 0 & 0 & $12 *$ \\
\hline S.a CCMB 285 & 0 & 0 & 0 & 10 & 8 & 7 & 0 & 0 & 0 & 0 & 0 & 0 & 0 & 0 & 0 & $12 *$ \\
\hline S.c CCMB 281 & 0 & 0 & 0 & 0 & 0 & 0 & 0 & 0 & 0 & 0 & 0 & 0 & 0 & 0 & 0 & $10 *$ \\
\hline C.a CCMB 286 & 0 & 0 & 0 & 0 & 0 & 0 & 0 & 0 & 0 & 0 & 0 & 0 & 0 & 0 & 0 & $0 * *$ \\
\hline C.a CCMB 266 & 0 & 0 & 0 & 0 & 0 & 0 & 0 & 0 & 0 & 0 & 0 & 0 & 0 & 0 & 0 & $24 * *$ \\
\hline M.f CCMB 293 & 0 & 0 & 0 & 0 & 0 & 0 & 0 & 0 & 0 & 0 & 0 & 0 & 0 & 0 & 0 & $0 * *$ \\
\hline
\end{tabular}

B.c: Bacillus cereus; E.c: Escherichia coli; P.a: Pseudomonas aeruginosa; S.a: Staphylococcus aureus; S.c: Salmonella choleraesuis; C.a: Candida albicans; M.f: Malassezia furfur; C1: $1000 \mu \mathrm{g}$ extract/disc; C2: $500 \mu \mathrm{g}$ extract/disc; C3: $250 \mu \mathrm{g}$ extract/disc; Controls: chloramphenicol * $30 \mu \mathrm{g} /$ disc e Nystatin ** $10 \mu \mathrm{g} / \mathrm{disc}$.

Table 2 - Minimum inhibitory concentration (MIC) and minimum bactericide concentration (MBC) values in $\mathrm{mg} / \mathrm{mL}$ for $S$. coronata inflorescence extracts and fractions, chloramphenicol $(\mathrm{mg} / \mathrm{mL})$ and DMSO (\%).

\begin{tabular}{lccccccccccc}
\hline Microorganisms & AE & $\mathbf{D F}^{\mathbf{a}}$ & $\mathbf{E A F}^{\mathbf{a}}$ & $\mathbf{B F}^{\mathbf{a}}$ & $\mathbf{M E}$ & $\mathbf{H F}^{\mathbf{m}}$ & $\mathbf{D F}^{\mathbf{m}}$ & $\mathbf{E A F}^{\mathbf{m}}$ & $\mathbf{B F}^{\mathbf{m}}$ & $\mathbf{C H L}^{\text {DMSO }}$ \\
\hline MIC & & & & & & & & & & & \\
\hline B.c CCMB 282 & 0,19 & 1,56 & 1,56 & 1,56 & 0,78 & 0,78 & 0,78 & 0,19 & 0,39 & 0,09 & 12,5 \\
S.a CCMB 262 & 0,78 & 0,78 & 1,56 & 3,12 & $*$ & $*$ & $*$ & $*$ & $*$ & 1,56 & 12,5 \\
S.a CCMB 263 & 0,78 & 1,56 & 1,56 & 3,12 & $*$ & $*$ & $*$ & $*$ & $*$ & 1,56 & 12,5 \\
S.a CCMB 285 & 0,78 & 1,56 & 1,56 & 6,25 & $*$ & $*$ & $*$ & $*$ & $*$ & 1,56 & 12,5 \\
\hline MBC & & & & & & & & & & & \\
\hline B.c CCMB 282 & 0,78 & 1,56 & 6,25 & 3,12 & 0,78 & 1,56 & 1,56 & 0,39 & 0,39 & 0,19 & 12,5 \\
S.a CCMB 262 & 3,12 & 6,25 & 6,25 & 6,25 & $*$ & $*$ & $*$ & $*$ & $*$ & 3,12 & 12,5 \\
S.a CCMB 263 & 3,12 & 6,25 & 6,25 & 6,25 & $*$ & $*$ & $*$ & $*$ & $*$ & 3,12 & 12,5 \\
S.a CCMB 285 & 3,12 & 6,25 & 6,25 & 6,25 & $*$ & $*$ & $*$ & $*$ & $*$ & 3,12 & 12,5 \\
\hline B.: Baclus cer
\end{tabular}

B.c: Bacillus cereus; S.a: Staphylococcus aureus; AE: crude aqueous inflorescence extract; ME: crude methanol inflorescence extract; HF: hexane fraction; DF: dichloromethane fraction; BF: butanol fraction; EAF: ethyl acetate fraction; a: fractions of the aqueous inflorescence extract; m: fractions of the methanol inflorescence extract; CHL: chloramphenicol; DMSO: dimethyl-sulfoxide; “*”: Test not performed due to lack of inhibition of the methanolic crude extract of the inflorescence, using the disk diffusion test. 


\section{DISCUSSION}

The inflorescence was the only among all the investigated parts of $S$. coronata to show any antimicrobial activity. The aqueous extract was effective against $B$. cereus and the three strains of $S$. aureus, with no distinction between the two antibiotic-resistant strains and the antibioticsensitive strain, while the methanol extract was effective only against $B$. cereus (Table 1). According to the criteria of Aligiannis et al. (2001), aqueous extracts from the inflorescence of S. coronata showed moderate activity (MIC $=0.78$ $\mathrm{mg} / \mathrm{mL}$ ) against $S$. aureus strains and strong activity (MIC $=0.19 \mathrm{mg} / \mathrm{mL}$ ) against B. cereus, while the methanol extract showed moderate activity ( $\mathrm{MIC}=0.78 \mathrm{mg} / \mathrm{mL}$ ) against $B$. cereus.

The MBC of the aqueous inflorescence extract of $S$. coronata against the strains $S$. aureus CCMB 262, 285 and 263 and B. cereus was four times higher than the respective MIC. The MBC of the methanol inflorescence extract against $B$. cereus was identical to the MIC. The bactericide activity concentration of chloramphenicol was twice the MIC. Evaluation of the minimum bactericide activity pattern is very important, once direct and prolonged contact of the $S$. aureus strains with antibiotics may be related to the development of antimicrobial resistance (Bernardes et al. 2004). Silveira et al. (2005) investigated the antimicrobial activity of $S$. oleracea and observed that the substances in hexane extracts of the epicarp/mesocarp were likely to be primarily responsible for the antimicrobial activity against $S$. aureus when compared to ethanol extracts. These authors suggested that the substances in the hexane extracts were probably the main responsible for the antimicrobial activity of $S$. oleracea.

On the other hand, according to Table 2, the crude aqueous extract of $S$. coronata showed higher antimicrobial activity against $B$. cereus and $S$. aureus strains when compared with the fractions investigates. This could be explained by the molecular synergism in the said extract. The crude methanol inflorescence extract showed low antimicrobial activity against $B$. cereus when compared with the fractions of higher polarity $\left(\mathrm{FAE}^{\mathrm{m}}\right.$ and $\mathrm{FB}^{\mathrm{m}}$ ), which suggested that the antimicrobial activity of the inflorescence was mainly due to higher polarity compounds.

The antibacterial activity of the aqueous extract and more polar fractions of methanol extract could be related to the presence of phenolic compounds, mostly soluble as esters or heterosides in water and organic solvents (Mello and Santos 2001) that formed complex with extracellular proteins of the bacterial membrane, leading to cell death (Cowan 1999).

No antimicrobial activity was observed in the aqueous and methanol extracts against the Gramnegative strains investigated, unlike the $S$. oleracea, which was effective against $P$. aeruginosa and $E$. coli in the studies conducted by Silveira et al. (2005). Some studies have shown that Gram-negative bacteria are not as susceptible to the plant extracts when compared to Grampositive (Ojala et al. 2000, Sanches et al. 2005, Mothana et al. 2008). The resistance of Gramnegative bacteria to antibacterial substances has been demonstrated by the presence of liposaccharides on the external membrane (Gao et al. 1999), as well as by the presence of enzymes capable of breaking down the substances introduced in the periplasmic space (Duffy and Power 2001).

None of the study extracts were effective against C. albicans and M. furfur. This could be due to the fungal cell wall acting as protective barrier against the extracts, or due to the latter not affecting or inhibiting the cell wall formation mechanisms. The results of this study, thus, showed that the use of liquid endosperm in folk medicine for the treatment of mycoses was not scientifically sound. The results of this study also pointed to the potential antimicrobial properties of $S$. coronata inflorescences. New trials are required, with the isolation and identification of bioactive substances, to aim to find out new therapeutic alternatives for the infections caused particularly by antibiotic-resistant $S$. aureus strains.

\section{ACKNOWLEDGEMENTS}

Authors thank to Professor Flávio França for his help with the identification of plant samples.

\section{REFERENCES}

Agra MF, Silva, KN, Basílio, JLD, Freitas, PF, BarbosaFilho, JM. Survey of medicinal plants used in the region Northeast of Brazil. Braz J Pharmacogn. 2008; 18: 472508. 
Aligiannis N, Kalpoutzakis E, Mitaku S, Chinou I. Composition and antimicrobial activity of the essential oils of two Origanum species. J Agri Food Chem. 2001; 49: 4168-4170.

Baue AW, Kirby WMM, Sherris JC, Turck M. Antibiotic susceptibility testing by a standardized single disc method. Amer J Clin Pathol. 1966; 45: 493-496.

Bernardes RC, Jorge AOC, Leão MVP. Sensibilidade à oxacilina, vancomicina e teicoplanina de Staphylococcus coagulase positivos isolados de pacientes hospitalizados em São José dos Campos. Rev Bioc. 2004; 10: 73-78.

Bondar G. O licuriseiro e suas possibilidades na economia brasileira. Instituto Central de Fomento Econômico da Bahia. 1938; 2: 18.

Chechinel Filho V, Yunes RA. Estratégias para obtenção de compostos farmacologicamente ativos a partir de plantas medicinais. Conceitos sobre modificação estrutural para otimização da atividade. Quim Nova. 1998; 21: 99-105.

CLSI. Clinical and Laboratory Standards Institute, formely NCCLS (National Committee for Clinical Laboratory Standards). Methods for Diluition Antimicrobial Susceptibility Test for Bacteria That Grow Aerobically; Approved Standard - NCCLS document M7-A6; 6 ed. Wayne, Pennsylvania- USA; 2003.

Cowan MM. Plant products as antimicrobial agents. Clin Microbiol Rev. 1999; 12: 564-582.

Crepaldi IC, Salatino A, Rios A. Syagrus coronata and Syagrus vagans: Traditional exploitation in Bahia, Brazil. Palms. 2004; 48: 43-48.

Custódio DL, Burgo RP, Moriel B, Barbosa AM, Rezende MI, Daniel JFS, Pinto JP, Bianchini E, Faria TJ. Antimicrobial activity of essential oils from Pimenta pseudocaryophyllus and Tynanthus micranthus. Braz Arch Biol Technol. 2010; 53: 1363-1369.

Duffy CF, Power RF. Antioxidant and antimicrobial properties of some Chinese plant extracts. Int $J$ Antimicrobiol Agents. 2001; 17: 527-529.

Esquenazi D, Wigg MD, Miranda MMFS, Rodrigues HM, Tostes JBF, Rozental S, Silva AJR, Alviano CS. Antimicrobial and antiviral activities of polyphenolics from Cocos nucifera Linn. (Palmae) husk fiber extract. Res Microbiol. 2002; 153: 647-652.

Gao Y, Belkum MJV, Stiles M. The outer membrane of Gram-negative bacteria inhibits antibacterial activity of Brochocin C. Appl Environ Microbiol. 1999; 65: 43294333.

Gonçalves CM, Lopes KGS, Crepaldi IC, Góes-Neto A, Uetanabaro APT. Ocorrência de microrganismos em ração animal preparada artesanalmente a partir do licuri (Syagrus coronata). Sitientibus Ser Ci Biol 2005; 5: 5355.

Hadi S, Bremner JB. Initial studies on alkaloids from Lombok medicinal plants. Molecules. 2001; 6: 117-129.

Hulin V, Mathot AG, Mafart P, Dufossé L. Les proprietés anti-microbiennes des huiles essentielles et composés d'arômes. Sciences des Aliments. 1998; 18: 563-582.
Lorenzi H. Árvores brasileiras: manual de identificação e cultivo de plantas arbóreas nativas do Brasil. 3. ed. v. 1. São Paulo: Instituto Plantarum; 2000.

Mello JPC, Santos SC. Taninos. In: Simões CMO, Schenckel EP (orgs) Farmacognosia: da planta ao medicamento. 3. ed. UFSC: Porto Alegre; 2001.

Mothana RAA, Abdo SAA, Hasson S, Althawab FMN, Alaghbari SAZ, Lindequist U. Antimicrobial, antioxidant and cytotoxic activities and phytochemical screening of some yemeni medicinal plants. eCAM. 2008; 1-8.

Noblick LR. The indigenous palms of the state of Bahia, Brazil [Tesis doctoral]. University of Illinois, Chicago; 1991.

Ojala T, Remes S, Haansuu P, Vuorela H, Hiltunen R, Haahtela K, Vuorela P. Antimicrobial activity of some coumarin containing herbal plants growing in Finland. $J$ Ethnopharmacol. 2000; 73: 299-305.

Rufino MUL, Costa JTM, Silva VA, Andrade LHC. Conhecimento e uso do ouricuri (Syagrus coronata) e do babaçu (Orbignya phalerata) em Buíque, PE, Brasil. Acta Bot Bras. 2008; 22: 1141-1149.

Sadrim JJC, Rocha MFG. Micologia Médica à luz de autores contemporâneos. 1. ed. Rio de Janeiro: Guanabra Koogan; 2004.

Sanches NR, Cortez DAG, Schiavini MSS, Nakamura CV, Dias Filho BP. An evaluation of antibacterial activities of Psidium guajava (L.). Braz, Arch Biol Technol. 2005; 48: 429-436.

Selitrennikoff CP. Screening for antifungal drugs. In: Finkeelstein D, Ball C (org) Biotechnology of filamentous fungi. Techonology and products. Boston: Butterworth Heinemann; 1992. p. 189-217.

Silveira CS, Pessanha CM, Lourenço MCS, Neves-Junior I, Menezes FS, Kaplan MAC. Atividade antimicrobiana dos frutos de Syagrus oleracea e Mauritia vinifera. Rev Bras Farmacogn. 2005; 15: 143-148.

Uhl NW, Dransfield J, Davis JI, Hansen KS, Doyle JJ. Phylogenetic relationships among palms: cladistic analyses of morphological and chloroplast DNA restriction site variation. In: Rudall PJ, Cribb PJ, Cutler DF, Humphries CJ (org) Monocotyledons: systematics and evolution, Kew: Royal Botanic Gardens; 1995. p. 623-661.

Venkataraman TR, Ramanujam TR, Venkatasubbu VS. Antifungal activity of the alcoholic extract of coconut shell Cocos nucifera Linn. J Ethnopharmacol. 1980; 2: 291-293.

Vieira OMC, Santos MH, Silva GA, Siqueira AM. Atividade antimicrobiana de Struthanthus vulgaris (erva-de-passarinho). Rev Bras Farmacogn. 2005; 15: 149-154.

Received: July 13, 2011; Revised: March 06, 2012; Accepted: September 21, 2012. 